\title{
The Attitudes of Deconverted and Lifelong Atheists Towards Religious Groups : The Role of Religious and Spiritual Identity
}

\section{Pauha, Teemu}

2020-10-01

Pauha , T , Renvik, T A, Eskelinen , V , Jetten , J , van der Noll , J , Kunst , J R , Rohmann , A \& Jasinskaja-Lahti , I 2020 , ' The Attitudes of Deconverted and Lifelong Atheists Towards Religious Groups : The Role of Religious and Spiritual Identity ' , International Journal for the Psychology of Religion, vol. 30 , no. 4 , pp. 246-264 . https://doi.org/10.1080/10508619.2020.177420

http://hdl.handle.net/10138/332690

https://doi.org/10.1080/10508619.2020.1774206

unspecified

acceptedVersion

Downloaded from Helda, University of Helsinki institutional repository.

This is an electronic reprint of the original article.

This reprint may differ from the original in pagination and typographic detail.

Please cite the original version. 


\section{The Attitudes of Deconverted and Lifelong Atheists towards Religious}

\section{Groups: The Role of Religious and Spiritual Identity}

Teemu Pauha* ${ }^{\mathrm{a} *}$, Tuuli Anna Renvik ${ }^{\mathrm{a}}$, Viivi Eskelinen ${ }^{\mathrm{a}}$, Jolanda Jetten ${ }^{\mathrm{b}}$, Jolanda van der Noll ${ }^{\mathrm{c}}$, Jonas R. Kunst ${ }^{\mathrm{d}}$, Anette Rohmann ${ }^{\mathrm{c}}$, and Inga Jasinskaja-Lahti ${ }^{\mathrm{a}}$

${ }^{a}$ University of Helsinki, Helsinki, Finland; ${ }^{b}$, University of Queensland, Brisbane, Australia; ${ }^{c}$, FernUniversität in Hagen, Hagen, Germany; ${ }^{d}$, University of Oslo, Oslo, Norway

*Teemu Pauha (teemu.pauha@helsinki.fi; https://orcid.org/0000-0002-2922-7538), Faculty of Theology, P.O 4 (Vuorikatu 3), 00014 University of Helsinki, Finland 


\title{
The Attitudes of Deconverted and Lifelong Atheists towards Religious Groups: The Role of Religious and Spiritual Identity
}

\author{
Increasing atheism, or the view that there is no God, is a major trend affecting the \\ Western religious landscape. Scholarly interest in atheists has grown together \\ with their number, but unanswered questions abound. In this study, we present \\ survey data $(\mathrm{N}=758)$ collected from deconverted and lifelong atheists in four \\ countries (Australia, Finland, Germany, and Norway), and investigate the \\ relationships between deconversion, religious/spiritual identity, and attitudes \\ towards the national religious majority, religious minorities in general, and \\ Muslims in particular. We show that having a religious or spiritual identity is \\ more typical for deconverts than life-long atheists. Furthermore, we demonstrate \\ that the higher religious or spiritual identity among deconverts is associated with \\ more positive attitudes towards different religious groups (national religious \\ majority, religious minorities in general, and Muslims specifically).
}

Keywords: atheism; deconversion; religious identity; attitudes; intergroup relations

\section{Introduction}

Increasing atheism, or the view that there is no God, is one of the major trends affecting the Western religious landscape today (e.g., Zuckerman, 2007). Pew Research Center (2015) has estimated that, between 2010 and 2050, the number of religiously unaffiliated Europeans will increase from 140 million to 162 million, or from 19 percent to 23 percent of the population. In the same time period, Australia is expected to experience even more profound change, with Christianity losing its status as the majority religion and the share of the unaffiliated population growing from 24 to 40 percent.

Despite their increasing numbers, non-believers have so far received little attention in the psychology of religion (Pérez \& Vallières, 2019). Furthermore, research 
typically contrasts atheism with religiosity, but the existing literature has so far not unpacked the conceptualisation of atheism (Streib \& Klein, 2013). In this paper, we present a more nuanced conception of atheism by making a distinction between deconverted and lifelong atheists, on one hand, and between (non)belief and religious/spiritual identity on the other. According to Streib and Klein (2013), it is important to conceptualise atheism as a process and, therefore, to study it together with deconversion. Schiavone and Gervais (2017) have likewise urged scholars of atheism to be mindful of potential psychological differences between deconverted and lifelong atheists. To our knowledge, such differences have not been previously investigated.

In the context of this study, we adhere to a working definition of "atheism" as "not believing in a God" (cf. Bullivant, 2013), and therefore treat "atheist" and "nonbeliever" as synonyms. We consider atheism, thus defined, as conceptually and empirically distinct from being non-religious/non-spiritual or having a nonreligious/non-spiritual identity. Although in popular thought and research alike, atheism and non-belief are typically conflated with non-religiousness (Streib \& Klein, 2013), belief (e.g., in God) is only one of many aspects of religiosity (e.g., Keysar, 2014; Smart, 1996) and non-believers may participate or adhere to these other aspects. Despite rejecting God, some non-believers are highly active participants in religious institutions (Hood \& Chen, 2013). For example, approximately one-quarter to one-half of Finnish atheists are members of the majority church, the Evangelical Lutheran Church of Finland (Taira, 2014). Furthermore, even a complete disaffiliation from religious communities does not imply a wholesale rejection of everything religious, as is evidenced, for example, by international bestsellers with titles like Religion for Atheists (de Botton, 2012) and "atheist churches" like the British-origin Sunday Assembly (Sillfors, 2017). Hence, despite the majority of atheists considering themselves as non- 
religious, there are also many who either have close associations with religious institutions or embrace beliefs and practices typical of religious and "spiritual" traditions (e.g., Sevinç, Coleman, \& Hood, 2018). Even though atheism and religiosity are regularly considered to be polar opposites, there are thus good reasons to see the two as partly overlapping categories_-or, as Beyer (2015) has put it, as a continuum with no clear line separating the one from the other.

Aside from deconversion and religious/spiritual identity, we investigate also the attitudes that atheists have towards those with a religious worldview. In religiously increasingly diverse societies — such as Australia, Germany, Finland, and Norway that are in focus here - the dialogue between different (non)religious groups is becoming ever more important. Previous studies have uncovered alarming levels of anti-atheist prejudice among both Christians (e.g., Cook, Cohen, \& Solomon, 2015; Gervais, 2011, 2013; Gervais \& Norenzayan, 2013; Gervais, Shariff, \& Norenzayan, 2011; Simpson \& Rios, 2017) and religious minorities, such as Muslims (e.g., Verkuyten, 2007).

However, fewer studies have examined the attitudes that atheists have towards religious people, but there is some evidence suggesting that non-believers may also have negative views of those with a different worldview (see also Ysseldyk, Haslam, Matheson, \& Anisman, 2012). In a Belgian study on stereotypes and meta-stereotypes of groups with opposite religious worldviews, for example, both believers and non-believers held negative stereotypes of their respective outgroup (Saroglou, Yzerbyt, \& Kaschten, 2011).

In this study, we focus on attitudes of atheists towards various religious groups (national religious majority, religious minorities in general, and Muslims) in four Western societies (Australia Finland, Germany, and Norway). We take account of the non-binary nature of a (non)religious worldview (Cotter, 2015), and are mindful of the 
idea that religiosity and spirituality may also be common among those who selfcategorize as non-believers (Sillfors, 2017; Taira, 2012). Further, we include deconversion as a factor in our analysis and argue that having a religious or spiritual identity is more typical for deconverted than life-long atheists: As the current paradigm of (de)conversion (Hood, Hill, \& Spilka, 2009) emphasizes, worldviews are not changed completely and abruptly when people deconvert. Despite losing or rejecting faith in God, deconverts may have retained other elements of their former religious or spiritual identity.

Furthermore, the common ingroup identity model (Gaertner \& Dovidio, 2000) suggests that intergroup attitudes may be improved if members of separate groups identify with some common superordinate category. Kunst, Thomsen, and Sam (2014), for example, have shown that the acknowledgement of a common Abrahamic heritage predicts positive interreligious attitudes among Muslims and Christians. That is, those Muslims and Christians who endorsed a shared/common Abrahamic group in addition to their own specific religious identities were more positive towards each other than those who did not hold such dual identities (see also Kunst et al., 2018). In this paper, we propose that the residual religious identity may similarly provide a deconvert with a dual identity (e.g., that of "a religious atheist") (cf. Dovidio, Gaertner, \& Saguy, 2009). Such a dual identity may make deconverts less likely to engage in boundary construction against religious people, which in turn should manifest itself as an increased positivity towards those with a religion. In support of this proposition, we aim to show, first, that deconverts are generally more positive towards various religious groups than life-long atheists, and, second, that this difference is explained by their higher religious or spiritual identity. To our knowledge, this is the first time that 
deconversion or religious/spiritual identity has been explored when investigating the interreligious attitudes of atheists.

\section{Deconverted and Lifelong Atheists}

Conversion, or the adoption of a new worldview, is a classic research topic in the psychology of religion (for a review, see Hood, Hill, \& Spilka, 2009). However, compared to the plethora of studies examining conversion, there are relatively few that discuss deconversion, or the abandonment of a previously held worldview (but see Streib et al., 2009; Van Nieuwkerk, 2018).

So far, most models of deconversion are based on research on conversion. The initial conceptualisations of conversion were heavily influenced by Evangelical Christianity and tended to perceive Saul's experience on the road to Damascus as a paradigmatic example of the phenomenon. Conversion was understood as a one-time event and a complete turning point in which an entire belief system was replaced by a new one (Hood, Hill, \& Spilka, 2009). Such "crisis conversions" have since been shown to be rare phenomena. Rather than changing an entire belief system in an instant, people shed old beliefs and acquire new ones gradually and with much active reflection (Pérez \& Vallières, 2019; Streib et al., 2009; Streib \& Keller, 2004). Similarly, loss of faith in God implies neither a complete abandonment of the whole belief system nor disaffiliation from the religious community. Pérez and Vallières (2019, p. 10), for example, stated in reference to their deconverted informants that "the strength of an individual's belief system typically weakened before adopting an atheist identity, going through stages of spiritualism, theism, or agnosticism." As discussed by Lewis (2003), even deconverts from controversial and stigmatised religions are likely to retain a large portion of their former faith. Brinkerhoff and Burke (1980), in turn, have made a 
distinction between Ritualists and Apostates, both of whom have lost their religious beliefs, but who differ with regard to the meaning they attach to religion. Apostates have severed all connection with their former religious community, whereas Ritualists still practice their faith, but for social instead of ideological reasons. Furthermore, even a complete disaffiliation, such as in the case of Apostates, does not necessarily lead to antagonism towards the abandoned group. On the contrary, deconverts often feel ambivalent or even positive about the movements that they have left (Lewis, 2003).

Despite having beliefs and practices that resemble those of organised religion, some atheists shun the word "religion" and prefer to identify as "spiritual" instead. The latter term is usually defined in opposition to the former: religion is perceived as organised, dogmatic, and other-worldly, whereas spirituality is seen as unorganised, non-dogmatic, and this-worldly (e.g., Popp-Baier, 2010). The term spirituality is typically used in reference to existential and ethical thinking or to experiences of the sacred and the sublime, especially as they take place outside the institutional boundaries of organised religion. The demarcation of spirituality from organised religion has made the former a popular concept among atheist thinkers (e.g., Antinoff, 2010; ComteSponville, 2006; Harris, 2014), who wish to appropriate aspects of religiosity, while at the same time maintaining a strict juxtaposition between being atheist and being religious (Taira, 2012). Therefore, including spiritual identity into our analysis allows us to grasp a broader spectrum of atheist identities. ${ }^{1}$

\footnotetext{
${ }^{1}$ Despite using both the terms "religion" and "spirituality," we endorse neither a clear-cut demarcation between the two nor a specific (etic) definition for either of them. As religion scholars such as Taira $(2013,2010)$ have emphasised, "religion" does not have a sui generis nature, but it is a classificatory device - a label that can be attached to different phenomena,
} 


\section{The Attitudes of Deconverts and Lifelong Atheists towards Religious Groups}

So far, there have been several studies on attitudes of religious people towards non-

believers (e.g., Cook, Cohen, \& Solomon, 2015; Gervais, 2011, 2013; Gervais \&

Norenzayan, 2013; Gervais, Shariff, \& Norenzayan, 2011; Simpson \& Rios, 2017). Far

fewer studies have examined the other side of the coin, namely attitudes of non-

believers towards religious people.

Guenther (2014) has demonstrated how atheists construct social and symbolic

boundaries between themselves and at least some religious groups (e.g., religious

leaders and evangelical Protestants). However, as Guenther (2014) herself notes, her

respondents were activists of atheist organisations and therefore did not represent non-

believers more generally. Jackson and Hunsberger (1999) studied a more diverse group

of non-believers and concluded that, on average, they had positive attitudes towards

religious people. According to Jackson and Hunsberger (1999), non-believers do not

generally consider religious people as an outgroup, but an exception to this may be the

most committed atheists, for whom non-religiousness is a central part of their self-

concept. Kossowska, Czernatowicz-Kukuczka, and Sekerdej (2017) demonstrated a link

between dogmatic atheism and anti-Catholic prejudice. According to the authors,

dogmatic atheists tend to understand religious statements literally and refute them on

scientific or rational grounds. However, there is also another, more symbolic, kind of

for example, in order to advance political goals related to them. The same applies, of course,

to spirituality. As a result, there can be no universal definition of either religion or

spirituality. Importantly, we do not require one for this study. We are simply interested in

whether our respondents consider themselves as religious or spiritual, whatever they mean

by that. 
atheism that is characterised by respect for other people's convictions and search for personally meaningful beliefs (Kossowska et al., 2017).

Saroglou, Yzerbyt, and Kaschten (2011) investigated how believers and nonbelievers view and imagine being viewed by each other. The researchers found that the attitudes of the two groups towards each other were equally positive. However, compared to believers, non-believers perceived their ingroup more favourably. This intergroup bias among non-believers was linked to attributing less altruism to believers and assuming that believers perceive non-believers as being low in honesty and conservatism, but high in hedonism and dogmatism.

A recent study by Uzarevic, Saroglou, and Muñoz-García (2019) is especially important for the present research because it deals with attitudes that self-categorized atheists and agnostics in Spain, France, and the United Kingdom have towards different religious groups (Catholics, Muslims, and Buddhists). In their study, compared to believers, non-believers were more prejudiced towards antiliberal groups (antigay activists and religious fundamentalists) but also towards regular Catholics. A similar pattern of results was found in all three countries involved in the study. According to the authors, this suggests that the link between non-belief and prejudice is not specific to a certain context.

Taken together, the previous studies seem to suggest that, similar to religious people, atheists may hold prejudiced beliefs towards those with a different worldview. However, it may be that atheism as such does not lead to negative attitudes towards religious people, but some varieties of atheism do. As noted above, previous studies have largely failed to account for the complexity of atheist identities (Streib \& Klein, 2013). To address this gap, we distinguish here between two different sub-groups of atheists on the basis of their deconversion status. 


\section{Present Study}

In this study, we analyse community samples of non-believers in four countries (Australia, Finland, Germany, and Norway). All four countries in the study are nominally majority Christian, but the actual level of religious practice is relatively low, with less than 20 percent of the population in each country being active in a religious organisation or attending religious services on a monthly basis. Finland and Norway are both $70-80 \%$ Lutheran countries, whereas in Australia and Germany, Christians form $60 \%$ of the population and are almost equally divided between Catholics and Protestants. The share of the religiously unaffiliated ranges from $7 \%$ in Norway to $27 \%$ in Germany (http://thearda.com/internationalData/index.asp). Studying atheists in these four countries allows us to determine whether any results that we obtain are countryspecific, or whether they apply more generally in industrialized, Western contexts that are historically Christian but characterized by increasing religious diversity and nonaffiliation.

As outlined above, in this study, we make a conceptual distinction between (non)belief and religious/spiritual identity: Being a non-believer does not necessarily imply a complete rejection of everything religious and spiritual, but some non-believers may very well identify with a religious or spiritual way of life. We make a further distinction between deconverted and life-long atheists. As noted above, the current research in the psychology of religion has demonstrated that a typical deconversion process may take place gradually and be only partial. Worldviews are not changed completely and instantly, but the worldview of a deconvert may still involve a religious or spiritual component. Based on this line of research and the current paradigm of (de)conversion (Hood, Hill, \& Spilka, 2009), we hypothesise: 
H1: Compared to lifelong atheists, deconverts consider themselves as more religious and more spiritual.

We suggest that a self-categorized non-believer who holds a religious/spiritual identity may possess a dual identity (e.g., that of "a religious atheist") (cf. Dovidio, Gaertner, \& Saguy, 2009). Such a dual identity may reduce the tendency to construct an intergroup boundary between atheists and religious people, or at least the religious majority. This, in turn, should manifest itself as more positive attitudes towards religious people. In this paper, we investigate the attitudes that deconverted and lifelong atheists have towards three different religious groups: the national religious majority, religious minorities in general, and Muslims specifically. We are, above all, interested in how deconversion status (that is, being a lifelong atheist or deconvert) relates to attitudes towards the aforementioned groups. On the basis of the reasoning outlined above, we propose the following hypothesis:

H2: Deconversion status is associated with a more positive attitude towards the national religious majority due to the higher religious/spiritual identity among deconverts compared to life-long atheists.

Whether religious and spiritual identity positively affect also the attitudes towards religious groups perceived as marginal or even "foreign" is, for us, an open question. On the one hand, it may be that a religious/spiritual identity provides affinity with religious people and a religious mindset in general. On the other hand, a religious/spiritual identity may involve a perception of other religions as rivals, which may even increase interreligious bias. In this paper, we expect to find a positive relationship between religious/spiritual identity and attitudes towards the national religious majority, but adopt an exploratory approach regarding the relationships 
between these different identities and attitudes towards other religions (religious minorities in general and Muslims).

To summarise, we have posited that because deconversion is typically a gradual and partial process, deconverts are likely to hold stronger religious and spiritual identities than life-long atheists. Religious or spiritual identity among atheists, in turn, may reduce the intergroup boundary between believers and non-believers, thus promoting positive interreligious attitudes. As a result, in comparison to lifelong atheists, we expect deconverts to be more positive towards at least the national religious majority due to their stronger religious and spiritual identities.

Because the religious landscape is relatively alike in our four research contexts (Australia, Finland, Germany, Norway), and because Uzarevic, Saroglou, and MuñozGarcía (2019) have demonstrated interreligious attitudes of atheists to be similar across nations, we expect to observe the same pattern of results in all four national subsamples. More specifically, we expect the hypotheses $\mathrm{H} 1$ and $\mathrm{H} 2$ to hold among Australian, Finnish, German, and Norwegian atheists alike.

\section{Method}

\section{Data and Participants}

The data was collected in 2017-2018 as part of a broader project on religiosity and intergroup relations. Community samples of the adult majority population were surveyed online or via telephone in four countries: Australia, Finland, Germany, and Norway. The survey was administered by either private survey companies (in Finland, Germany, and Australia) or research assistants (in Norway). Altogether, 1,792 respondents participated in the study (514 Australians, 440 Finns, 421 Germans, and 
415 Norwegians). Participation was voluntary and anonymous. We excluded nonnational citizens with an immigrant background $(\mathrm{N}=89)$ as well as all participants who gave a negative response to a control question in which they were asked to commit themselves to completing the questionnaire truthfully $(\mathrm{N}=4)$.

Respondents were asked to choose which one, out of four, statements best described their belief in God: "I don't believe in God now and I never have," "I don’t believe in God now, but I used to," "I believe in God now, but I didn't use to," and "I believe in God now and I always have." In this study, we focus on the 758 respondents who chose either of the first two items as most descriptive of their beliefs and were thus classified as non-believers. From these, 292 chose the response option "I don't believe in God now, but I used to" as most descriptive of their beliefs. We refer to this group as "deconverted atheists" (or simply "deconverts"). The remaining 466 respondents, in contrast, chose the response option "I don't believe in God now and I never have" and were thus classified as "lifelong atheists."

All of our respondents fulfilled our working definition of atheism as not believing in a God, but not all of them considered themselves as atheists (cf. Cotter, 2015, p. 176). ${ }^{2}$ For example, in the Australian subsample of non-believers, 57 percent identified as atheists, 24 percent as agnostics, and 19 percent as Christians. This shows that besides the literal meaning of there being no God (Gr. a-theos), the word atheism carries a number of common connotations. ${ }^{3}$

\footnotetext{
${ }^{2}$ Similarly, Catto and Eccles (2013) have noted that there are a lot more people stating in surveys that they do not believe in God than there are people identifying as atheists.

${ }^{3}$ A number of researchers have shown that atheism is associated, for example, with immorality and untrustworthiness (e.g., Brown-Iannuzzi, McKee, \& Gervais, 2018; Gervais, Shariff, \&
} 
The gender distribution was equal between the deconverted and lifelong atheists, $\chi^{2}(1)=.68, p=.408:$ Of the 292 deconverts, $127(43.5 \%)$ were women and 165

(56.5\%) were men. Of the 466 lifelong atheists 217 (46.6\%) were women and 249

(53.4\%) were men. The age difference between the groups was not statistically significant, $t(547,78)=-.48, p=.632$ : the mean age for the deconverts was $45.5(S D=$ 17.0) years, and for the lifelong atheists it was $44.9(S D=14.5)$ years.

The proportion of deconverts was significantly different in different countries, $\chi^{2}$ (3) $=29.382, p<.002$ (see also Table 1). Pairwise $\chi^{2}$ comparisons indicated that deconverts were relatively more numerous in Australia and Finland than in Germany, $\chi^{2}$ $(1)=29.05, p<.001$ and $\chi^{2}(1)=9.56, p=.002$, respectively. ${ }^{4}$ The large share of lifelong atheists in the German subsample can probably be attributed to the religion policies in the former GDR, which made East Germany the least religious region in Europe with an exceptional number of "second generation atheists" (Casanova, 2009). A further difference was found between Australia and Norway: compared to Norway, the Australian sample included relatively more deconverts, $\chi^{2}(1)=8.38, p=.004$.

\section{Measures}

Attitudes towards the religious majority, religious minorities generally, and Muslims were measured by applying the feeling thermometer adopted from Verkuyten (2007). The general instruction for the thermometer was as follows: "Please evaluate to what extent you feel positive or negative emotions towards different religious groups in

Norenzayan, 2011), making it a stigmatised identity and, as such, less likely explicitly endorsed.

\footnotetext{
${ }^{4}$ Bonferroni correction was applied to account for multiple testing.
} 
[country]. Use the 'feeling thermometer' to indicate your feelings, where +50 degrees mean very positive or warm feelings, and -50 degrees mean very negative or cold feelings." The respondents were then asked to use the -50 to +50 scale to rate their feelings towards three categories of religious people: the national religious majority, religious minorities in general, and Muslims specifically.

Religious and spiritual identity were measured with two items respectively: "I consider myself to be a religious person" (or: "a spiritual person interested in the sacred or the supernatural") and "I feel myself being a member of a religious group" (or: "a spiritual group"). All items were answered on a 7-point scale where 1 means "not at all" and 7 means "very much so." Final religious and spiritual identity scores were calculated as averages of the respective items. Inter-item correlations for religious and spiritual identity were $r(756)=.62, p<.001$, and $r(756)=.49, p<.001$, respectively.

In regression analyses, we controlled for age, gender, education, and political orientation of the respondents. Education level was originally measured on a 6-point scale ranging from "primary school" to "doctoral degree." Because the scale used was ordinal, we recoded education level into two categories: university degree and lower education. Political orientation was measured on a 7-point scale where 1 means "I represent more the right wing" and 7 means "I represent more the left wing."

All analyses were performed using SPSS versions 24 and 25. Analysis syntaxes are available upon request.

\section{Results}

The descriptive statistics of the whole sample are presented in Table 1.

\section{[Insert Table 1 here]}


As can be seen in Table 1, respondents scored on average very low on the religious and spiritual identity scales. However, as predicted by H1, deconverts had, on average, stronger religious and spiritual identities than lifelong atheists (see Table 2). The difference was in the same direction in all four countries. However, an independentsamples $t$-test failed to reach significance for religious identity in Norway and for spiritual identity in Germany.

\section{[Insert Table 2 here]}

Compared to the lifelong atheists, deconverts also reported more positive attitudes towards the religious majority, religious minorities, and Muslims (see Table 3). Here again, the difference was in the same direction in all countries, with the exception of Germany, where lifelong atheists were marginally more positive towards the religious majority than deconverts were. However, the country-specific independent-samples $t$ tests demonstrated mostly non-significant results.

\section{[Insert Table 3 here]}

Next, we examined correlations between religious/spiritual identities and interreligious attitudes (see Table 4). In the whole sample, all of these variables were found to correlate positively and significantly. In particular, religious and spiritual identity were both associated with more positive attitudes towards religious groups. With regard to 
the separate country samples, religious identity and attitudes towards the religious majority correlated positively in Australia and Finland. The other country-specific correlations between religious/spiritual identities and interreligious attitudes were positive but non-significant.

\section{[Insert Table 4 here]}

To further investigate the relationship between deconversion status (lifelong atheist vs. deconvert) and attitudes towards religious groups via religious/spiritual identity, we performed several hierarchical regression analyses. ${ }^{5}$ We performed analyses separately for each dependent variable (attitudes towards the religious majority, minorities, and Muslims). ${ }^{6}$ In each analysis, we controlled for participants' gender, age, country, ${ }^{7}$

${ }^{5}$ Despite the high correlation between religious and spiritual identity (see Table 4), multicollinearity statistics did not indicate significant problems with the two variables being included in the same model. In the models introduced in Table 5, the VIF scores for religious and spiritual identity were 1.76 and 1.69 , respectively.

${ }^{6}$ We also constructed separate models for each country in the study. However, possibly because of the low number of deconverts in individual countries, the country-specific models failed to reach statistical significance. These results can be provided upon request from the authors.

${ }^{7}$ Finland was used as the reference category in the regression models because it had the highest mean score of the dependent variable (the feeling thermometer rating towards the religious majority). 
education, and political orientation. ${ }^{8}$ The results are displayed in Table 5.

\section{[Insert Table 5 here]}

Deconversion status was positively associated with more positive attitudes towards religious groups even after controlling for gender, age, country, education, and political orientation (see Model 1 columns in Table 5). More specifically, compared to lifelong atheists, deconverts were generally more positive towards all religious groups studied. However, when religious and spiritual identity were entered into the model, deconversion status lost its significance as an independent predictor (see Model 2 columns in Table 5), suggesting a potential indirect effect of deconversion status on attitudes via religious and spiritual identity.

We used the PROCESS macro (version 3.0; Hayes, 2017) to test the hypothesized mediation model and to compute the indirect effect of deconversion status on attitudes towards religious groups (see Table 6). Mediation analyses were conducted with the pooled data, and controlling for participants' gender, age, country, education, and political orientation.

\section{[Insert Table 6 here]}

\footnotetext{
${ }^{8}$ For this purpose, categorical variables (country and education) were transformed into dummy variables. Accordingly, the analysis involved three dummies for the four countries in the study and a fourth dummy separating those with and without university education.
} 
Deconversion status was a significant predictor of religious identity, which in turn was positively associated with attitudes towards the religious majority, religious minorities generally, and Muslims in particular. Deconversion status was also positively related to spiritual identity, but spiritual identity did not appear to be further associated with attitudes towards religious groups, with the exception of a small negative association between spiritual identity and attitudes towards Muslims. After controlling for religious and spiritual identities, deconversion status was no longer associated with attitudes towards any of the three religious groups. The indirect association between deconversion status and attitudes towards religious groups via religious but not spiritual identity was statistically significant in all models.

\section{Discussion}

In this study, we examined the attitudes towards religious groups among non-believers in four countries (Australia, Finland, Germany, and Norway). We focused in particular on the differences between deconverted and lifelong atheists in terms of their attitudes towards religious groups. We also investigated whether these differences could be attributed to differences in their religious/spiritual identity. We are not aware of any previous research that has compared the degree of religious and spiritual identification of these two groups. Finally, in this study, attitudes towards three religious groups were examined: national religious majority, minority religious groups in general, and Muslims.

In both academic and everyday discourse, it is common to treat atheism and religion as opposites. However, as our results demonstrate, not believing in God does not imply a complete lack of religiosity. Granted, our respondents scored, by and large, towards the very bottom of the religious and spiritual identity scales. However, the 
rejection of religion and spirituality was by no means uniform. The distributions of the identity scales were skewed, but nevertheless covered almost the whole range of possible scores.

All in all, our study shows that deconverts have, on average, somewhat stronger religious and spiritual identities than lifelong atheists. This may be due to deconverts being familiar with a religious mindset or holding on to at least some aspects of their former religious background. As indicated by the notion of intrinsic vs. extrinsic religiosity (Allport \& Ross, 1967), religious motivation may stem either from religion being an internalised belief system or from the social and other benefits that religion provides. Thus, the practice of religion is not necessarily motivated by belief in its metaphysical claims, but the reasons may be much more mundane-for example, gaining social acceptance or prestige (Neyrinck et al., 2010; Van Camp, Barden, \& Sloan, 2016). Our analyses also showed that, compared to the lifelong atheists, deconverts in our study held more positive views of the national religious majority, religious minorities in general, and Muslims in particular. Furthermore, this group difference in attitudes appears to be at least in part due to differences in the strength of religious and spiritual identity between these two groups of non-believers. A similar pattern of results was observed in all four research contexts (Australia, Finland, Germany, and Norway), suggesting that the positive associations between deconversion, religious/spiritual identity, and interreligious attitudes apply generally, at least among the majority populations in industrialized, Western, historically Christian societies.

In addition to the psychology of religion, identities based on worldviews are also studied in social psychology, and especially in the social identity theory (SIT). In what follows, we attempt to build bridges between our findings and the social psychology of intergroup relations. 
As outlined in SIT, social identity refers to "those aspects of an individual's selfimage that derive from the social categories to which (s)he perceives him or herself as belonging" (Tajfel \& Turner, 1979, p. 40). According to SIT, social identities are important sources of positive self-esteem and consequently, people are naturally disposed to favour those perceived as belonging to the same social category or “ingroup" (Tajfel \& Turner, 1979). Whether and when ingroup favouritism translates into outgroup hostility is a complex issue that depends on the meanings that are associated with the group membership. A feeling of one's ingroup's moral superiority or a perception of the outgroup as a threat are examples of factors that may increase perceived intergroup conflict and result in outgroup derogation (e.g., Brewer, 1999).

In theory, religiously identified atheists could define their in- and outgroups in two different ways. More specifically, an atheist with a religious identity may draw an intergroup boundary either between the religious and the non-religious or between one's own (former) religion and other religions. It is thus possible that, at least with regard to deconverts, religious and spiritual identities predict positive attitudes only towards one's own (former) religious community (the national religious majority) and neutral or even negative attitudes towards those with other faiths. However, as Carol, Helbling, and Michalowski (2015) have noted, the most salient religious boundary in the Western context is not necessarily between different religious groups but between the religious and the non-religious. Our findings lend further support to this view; if an atheist identifies with a religion, it appears to make them more sympathetic towards religious people in general.

While intergroup relations in general have been extensively studied within the social identity paradigm, there is currently little research on how those who switch 
groups, such as deconverts, perceive their former ingroup. ${ }^{9}$ Tentatively, the more positive attitudes of deconverts towards believers could be explained by two factors: categorisation and contact. First, it may be that deconverts are less likely than life-long atheists to categorise religious people as an outgroup (cf. Gaertner \& Dovidio, 2000). We suggested that this may be due to deconverts still holding on to certain elements of their former faith. By having ties with and understanding of the value system of both believers and non-believers, deconverts may thus become a "gateway group" that bridges the two groups (see Levy et al., 2017a, 2017b, 2017c).

Second, as the social psychological contact hypothesis states, positive contact experiences between groups are likely to foster positive intergroup attitudes (Allport, 1954). Previous studies have shown that religiosity is dependent on religious socialisation (e.g., Hood, Hill, \& Spilka, 2009); religious believers are likely to have relatives and friends who are also believers. Being former believers, deconverts probably also continue to engage in contacts with members of their former religious communities. However, as we did not study contact per se, future research could benefit from studying intergroup contact with regard to group switchers in general and deconverts in particular.

\footnotetext{
${ }^{9}$ As a noteworthy exception, the relationship of acculturating immigrants to their heritage
} culture (e.g., Liebkind et al., 2016; Phinney, 2003) has been studied extensively and this could be conceptualized as group switchers' attitude towards the (former) ingroup.

Furthermore, there is some research on how group switchers are perceived by other members of their former and current ingroups (e.g., Hornsey et al., 2007; Levine \& Moreland, 2002; Mannetti et al., 2010; Travaglino et al., 2014). 


\section{Limitations and Future Directions}

Although our study has shed light to the relatively understudied concept of deconversion and its ramifications for interreligious attitudes, it is not without limitations. As noted earlier, the label "atheist" is here used as a technical term that refers to anyone who does not believe in God. We are fully aware that some of our respondents are very likely to shun the label of an atheist, and to these respondents we apologise. However, for practical reasons, we need to use some terms, and as studies such as those conducted by Cotter (2015), Bullivant et al (2019), and Silver et al (2014, p. 993) make clear, there is no word that every "none" (cf. Vernon, 1968) would choose as a self-descriptor. Even though not universally approved, "atheist" appears to be the most widely accepted term of those available (cf. Bullivant et al., 2019; Cotter, 2015).

As our sampling was conducted on the basis of belief in God, it is for future studies to investigate whether the associations between deconversion status, religious/spiritual identity, and interreligious attitudes hold also in samples consisting exclusively of self-categorized atheists. It is also worth noting that, due to our research settings and exclusion of non-national citizens, our findings should not be generalized beyond the majority population in industrialized, Western, historically Christian contexts. It is possible that a non-Christian (for example, a Muslim) religious identity would have a different relationship to the interreligious attitudes of atheists.

Given that we have studied the religious and spiritual identities of a relatively non-religious population, it is not surprising that our identity measures suffered from a strong floor effect, with $67 \%$ of the respondents receiving the minimum score on the religious identity scale and $54 \%$ on the spiritual identity scale. As such, the scales do not necessarily differentiate between the different kinds of atheists at the bottom of the 
scale. Both anti-religious anti-theists and apatheists ${ }^{10}$ (cf. Beyer, 2015), for example, are likely to rate very low on any religious identity measure, despite having quite different relationships to religion. In order to better grasp the full spectrum of ways in which people (dis)identify with religion, future research would do well to develop and apply also explicit measures of non-religious identity. As noted by Verkuyten and Yildiz (2007), active disidentification (for example, with religion) is not the same as a mere absence of identification. Therefore, there is value in measuring both identification and disidentification separately.

It is worth noting that, as measured by regression coefficients and $\mathrm{R}^{2} \mathrm{~s}$, the effects of the deconversion status and religious/spiritual identity to attitudes towards religious groups were relatively small. This is not surprising, given that interreligious attitudes are determined by a number of factors aside from those analyzed here. Religious identity and deconversion do matter, but their importance should not be overstated.

Furthermore, despite being in the same direction, the country-wise differences between deconverts and life-long atheists were generally not statistically significant. This may largely be due to the relatively small number of deconverts in individual

\footnotetext{
${ }^{10}$ Not all non-believers are committed advocates of a non-theistic philosophy. There are some who are simply uninterested in all matters religious. These people do not deny God because of philosophical and scientific reasons, but because the existence of God is irrelevant to them (cf. Pauha \& Aghaee, 2018, pp. 346-347). Rauch (2003; see also von Hegner, 2016) has referred to such a position as "apatheism".
} 
countries or the small effect sizes. ${ }^{11}$ Our study thus provides preliminary evidence that the positive relationship of deconversion with religious/spiritual identity and interreligious attitudes applies generally in industrialized, Western contexts that are historically Christian but increasingly characterized by religious pluralism. This finding, however, needs to be confirmed and further elaborated in future studies.

In this study, we have adopted a cross-sectional design and compared people with and without a previous deconversion experience. However, as emphasized by the current paradigm of (de)conversion (Hood, Hill, \& Spilka, 2009), losing faith is typically not a one-time event but a prolonged process or part of a complex "conversion career." Accordingly, we do not know at which stage of the deconversion process our respondents are. It may be, for example, that a stronger religious or spiritual identity is more typical for a certain stage, but investigating this would require longitudinal research.

Such longitudinal investigations could perhaps benefit from the MARGINI model introduced by Ellemers and Jetten (2013) to clarify the dynamics of marginal group membership. Because atheism is typically conceived of as an opposite to religion, the respondents high in religious identity are less prototypical as atheists and, therefore, possibly marginal group members. Based on the MARGINI model, it may be predicted that an atheist may retain a strong religious identity if neither they themselves nor fellow atheists aim for greater inclusion into the atheist fold. In all other situations, either the strong religious identity or non-belief is likely to be temporary: If there is a convergence of group and individual inclusion goals in that the individual strives to

\footnotetext{
${ }^{11}$ Accordingly, the results were most consistently significant in the Australian sample, which also had the highest number of deconverts.
} 
become more like the other atheists and other atheists support this, a strong religious identity is likely to be a transitional stage in the process of being socialized as an atheist. If the goals diverge, in contrast, there is a tension that requires the individual to distance themselves from either religious people or atheists.

All in all, future research would do well to further elaborate the diversity of atheist identities and worldviews. Atheists are likely to differ from each other, for example, with regard to identity motives (see Vignoles, \& Moncaster, 2007) and modes of identification (see Roccas et al., 2008). Furthermore, what is also needed are ethnographic and other qualitative investigations into atheist meaning-making. We very much agree with Cotter (2015, p. 182) when he writes: “[W]hether we distinguish between the 'religious' and 'non-religious' in terms of identity, practice, beliefs etc., or any combination of these, we will very quickly run into trouble. [...] Whether someone is an 'atheist' or not tells us little about their (non)religiosity, their (non)religious history, or what (non)religion means to them in the real world."

\section{Conclusions and Practical Implications}

Despite increasing secularization and diversity resulting in secular but multi-religious and multi-convictional societies, people tend to live in ideologically segregated social environments which maintain and foster the development of negative attitudes and interreligious relations (Saroglou, Yzerbyt \& Kaschten, 2011). Our results demonstrate that, at least in certain circumstances, former members of a religious group hold more positive attitudes towards that group (and other religious groups) than those who have never been members. We suggest that this is largely due to former members still having social identity traces associated with their former group membership. Because of these traces, deconvert identity may perhaps serve as a kind of a dual identity (e.g., that of "a 
religious atheist"), thus weakening intergroup boundaries and reducing intergroup bias.

\section{Acknowledgments}

The authors wish to thank Prof. Antti Räsänen for his encouragement and support. After the project has ended (in 2024), the data used here will be made available and can be requested from the authors.

\section{References}

Allport, G. W. (1954). The nature of prejudice. Reading: Addison-Wesley.

Allport, G. W., \& Ross, J. M. (1967). Personal religious orientation and prejudice. Journal of Personality and Social Psychology, 5(4), 432-443.

Antinoff, S. (2010). Spiritual Atheism. Berkeley: Counterpoint.

Beyer, P. (2015). From Atheist to Spiritual but not Religious: A Punctuated Continuum of Identities among the Second Generation of Post-1970 Immigrants in Canada. In L. G. Beaman \& S. Tomlins (Eds.), Atheist Identities: Spaces and Social Contexts (pp. 137-151). Cham: Springer.

Brewer, M. B. (1999). The psychology of prejudice: Ingroup love or outgroup hate? Journal of Social Issues, 55(3), 429-444.

Brinkerhoff, M. B., \& Burke, K. L. (1980). Disaffiliation: Some notes on "falling from the faith". Sociological Analysis, 41(1), 41-54.

Brown-Iannuzzi, J. L., McKee, S., \& Gervais, W. M., (2018). Atheist Horns and Religious Halos: Mental Representations of Atheists and Theists. Journal of Experimental Psychology: General, 147(2), 292-297.

Bullivant, S. (2013). Defining ‘Atheism.' In S. Bullivant \& M. Ruse (Eds.), The Oxford Handbook of Atheism (pp. 11-22). Oxford: Oxford University Press. 
Bullivant, S., Farias, M., Lanman, J., \& Lee, L. (2019). Understanding Unbelief: Atheists and agnostics around the world: Interim findings from 2019 research in Brazil, China, Denmark, Japan, the United Kingdom and the United States. London: St Mary’s University, Twickenham. Retrieved from https://research.kent.ac.uk/understandingunbelief/wpcontent/uploads/sites/45/2019/05/UUReportRome.pdf

Carol, S., Helbling, M., \& Michalowski, I. (2015). A struggle over religious rights? How Muslim immigrants and Christian natives view the accommodation of religion in six European countries. Social Forces, 94(2), 647-671.

Casanova, J. (2009). The religious situation in Europe. In H. Joas \& K. Wiegandt (Eds.), Secularization and the World Religions (pp. 206-228). Liverpool: Liverpool University Press.

Catto, R., \& Eccles, J. (2013). (Dis)Believing and belonging: Investigating the narratives of young British atheists. Temenos, 49(1), 37-63.

Comte-Sponville, A. (2006). The Little Book of Atheist Spirituality. New York: Viking.

Cook, C. L., Cohen, F., \& Solomon, S. (2015). What if they're right about the afterlife? Evidence of the role of existential threat on anti-atheist prejudice. Social Psychological and Personality Science, 6(7), 840-846.

Cotter, C. R. (2015). Without God yet not Without Nuance: A Qualitative Study of Atheism and Non-religion among Scottish University Students. In L. G. Beaman \& S. Tomlins (Eds.), Atheist Identities: Spaces and Social Contexts (pp. 171193). Cham: Springer.

De Botton, A. (2012). Religion for Atheists: A Non-Believer's Guide to the Uses of Religion. London: Penguin. 
Dovidio, J. F., Gaertner, S. L., \& Saguy, T. (2009). Commonality and the complexity of "we": Social attitudes and social change. Personality and Social Psychology Review, 13(1), 3-20.

Ellemers, N., \& Jetten, J. (2013). The many ways to be marginal in a group. Personality and Social Psychology Review, 17(1), 3-21.

Gaertner, S. L., \& Dovidio, J. F. (2000). Reducing intergroup bias: The common ingroup identity model. Philadelphia: Psychology Press.

Gervais, W. M. (2011). Finding the faithless: Perceived atheist prevalence reduces antiatheist prejudice. Personality and Social Psychology Bulletin, 37(4), 543-556.

Gervais, W. M. (2013). In godlessness we distrust: Using social psychology to solve the puzzle of anti atheist prejudice. Social and Personality Psychology Compass, $7(6), 366-377$.

Gervais, W. M., \& Norenzayan, A. (2013). Religion and the origins of anti-atheist prejudice. In S. Clarke, R. Powell, \& J. Savulescu (Eds.), Intolerance and Conflict: A Scientific and Conceptual Investigation (pp. 126-146). Oxford, UK: Oxford University Press.

Gervais, W. M., Shariff, A. F., \& Norenzayan, A. (2011). Do you believe in atheists? Distrust is central to anti-atheist prejudice. Journal of Personality and Social Psychology, 101(6), 1189-1206.

Guenther, K. M. (2014). Bounded by Disbelief: How Atheists in the United States Differentiate themselves from Religious Believers. Journal of Contemporary Religion, 29(1), 1-16.

Harris, S. (2014). Waking Up: A Guide to Spirituality without Religion. New York: Simon \& Schuster. 
Hayes, A. F. (2017). Introduction to Mediation, Moderation, and Conditional Process Analysis. New York: The Guilford Press.

Hood, R. W. Jr., \& Chen, Z. (2013). Conversion and deconversion. In S. Bullivant \& M. Ruse (Eds.), The Oxford Handbook of Atheism (pp. 537-549). Oxford: Oxford University Press.

Hood, R. W., Jr., Hill, P. C., \& Spilka, B. (2009). The psychology of religion: An empirical approach. New York: Guilford Press.

Hornsey, M. J., Grice, T., Jetten, J., Paulsen, N., \& Callan, V. (2007). Group-directed criticisms and recommendations for change: Why newcomers arouse more resistance than old-timers. Personality and Social Psychology Bulletin, 33(7), $1036-1048$.

Jackson, L. M., \& Hunsberger, B. (1999). An intergroup perspective on religion and prejudice. Journal for the Scientific Study of Religion, 38(4), 509-523.

Keysar, A. (2014). Shifts along the American religious-secular spectrum. Secularism and Nonreligion, 3(1), 1-16.

Kossowska, M., Czernatowicz-Kukuczka, A., \& Sekerdej, M. (2017). Many faces of dogmatism: Prejudice as a way of protecting certainty against value-violators among dogmatic believers and atheists. British Journal of Psychology, 108, $127-147$.

Kunst, J. R., Kimel, S. Y., Shani, M., Alayan, R., \& Thomsen, L. (2018). Can Abraham Bring Peace? The Relationship between Acknowledging Shared Religious Roots and Intergroup Conflict. Psychology of Religion and Spirituality. Advance online publication.

Kunst, J. R., Thomsen, L., \& Sam, D. L. (2014). Late Abrahamic reunion? Religious fundamentalism negatively predicts dual Abrahamic group categorization among 
Muslims and Christians. European Journal of Social Psychology, 44(4), 337348.

Levine, J. M., \& Moreland, R. L. (2002). Group reactions to loyalty and disloyalty. In S. R. Thye \& E. J. Lawler (Eds.), Group cohesion, trust and solidarity (pp. 203228). New York: Elsevier Science/JAI Press.

Levy, A., Saguy, T., Van Zomeren, M., \& Halperin, E. (2017a). Ingroups, outgroups, and the gateway groups between: The potential of dual identities to improve intergroup relations. Journal of Experimental Social Psychology, 70, 260-271.

Levy, A., Saguy, T., Halperin, E., \& Van Zomeren, M. (2017b). Bridges or barriers? Conceptualization of the role of multiple identity gateway groups in intergroup relations. Frontiers in Psychology, 8, 1097-1117.

Levy, A., van Zomeren, M., Saguy, T., \& Halperin, E. (2017c). Intergroup emotions and gateway groups: Introducing multiple social identities into the study of emotions in conflict. Social and Personality Psychology Compass, 11(6), 1-15.

Lewis, J. R. (2003). Legitimating New Religions. New Brunswick: Rutgers University Press.

Liebkind, K., Mähönen, T. A. E., Varjonen, S. A., \& Jasinskaja-Lahti, I. (2016). Acculturation and Identity. In D. L. Sam \& J. W. Berry (Eds.), Cambridge Handbook of Acculturation Psychology, 2nd Edition (pp. 30-49). Cambridge: Cambridge University Press.

Mannetti, L., Levine, J. M., Pierro, A., \& Kruglanski, A. W. (2010). Group reaction to defection: The impact of shared reality. Social Cognition, 28(3), 447-464.

Neyrinck, B., Lens, W., Vansteenkiste, M., \& Soenens, B. (2010). Updating Allport's and Batson's framework of religious orientations: A reevaluation from the 
perspective of self-determination theory and Wulff's social cognitive model. Journal for the Scientific Study of Religion, 49(3), 425-438.

Pauha, T., \& Aghaee, A. (2018). “God never existed, and I was looking for him like crazy!” Muslim Stories of Deconversion. In K. van Nieuwkerk (Ed.), Moving In and Out of Islam (pp. 333-359). Austin: Texas University Press.

Pérez, S., \& Vallières, F. (2019). How Do Religious People Become Atheists? Applying a Grounded Theory Approach to Propose a Model of Deconversion. Secularism and Nonreligion, 8(3), 1-14.

Pew Research Center (2015). The Future of World Religions: Population Growth. Projections, 2010-2050. Washington: Pew Research Center.

Phinney, J. S. (2003). Ethnic identity and acculturation. In K. M. Chun, P. Balls Organista \& G. Marin (Eds.), Acculturation: Advances in theory, measurement, and applied research (pp. 63-81). Washington, DC: American Psychological Association.

Popp-Baier, U. (2010). From religion to spirituality - megatrend in contemporary society or methodological artefact? A contribution to the secularization debate from psychology of religion. Journal of Religion in Europe, 3(1), 34-67.

Rauch, J. (2003, May). Let it be. The Atlantic. Retrieved from https://www.theatlantic.com/magazine/archive/2003/05/let-it-be/302726/

Roccas, S., Sagiv, L., Schwartz, S., Halevy, N., \& Eidelson, R. (2008). Toward a unifying model of identification with groups: Integrating theoretical perspectives. Personality and Social Psychology Review, 12, 280-306.

Saroglou, V., Yzerbyt, V., \& Kaschten, C. (2011). Meta-stereotypes of groups with opposite religious views: Believers and non-believers. Journal of Community \& Applied Social Psychology, 21(6), 484-498. 
Schiavone, S. R., \& Gervais, W. M. (2017). Atheists. Social and Personality Psychology Compass, 11(12), 1-13.

Sevinç, K., Coleman, T. J., III., \& Hood, R. W., Jr., (2018). Non-Belief: An Islamic Perspective. Secularism and Nonreligion, 7(1), 1-12.

Sillfors, M. (2017). Jumalattomuus ja hyvä elämä: ateistinen henkisyys vaihtoehtona monoteistiselle uskonnolle 2000-luvun länsimaissa (Doctoral dissertation). Retrieved from http://urn.fi/URN:ISBN:978-951-51-3091-4

Silver, C. F., Coleman, T. J., III., Hood, R. W., Jr., \& Holcombe, J. M. (2014). The six types of nonbelief: A qualitative and quantitative study of type and narrative. Mental Health, Religion \& Culture, 17(10), 990-1001.

Simpson, A., \& Rios, K. (2017). The moral contents of anti-atheist prejudice (and why atheists should care about it). European Journal of Social Psychology, 47(4), 501-508.

Smart, N. (1996). Dimensions of the sacred: An anatomy of the world's beliefs. London: HarperCollins.

Streib, H., Hood, R. W., Jr., Keller, B., Csöff, R.-M., \& Silver, C. (2009). Deconversion: Qualitative and quantitative results from cross-cultural research in Germany and the United States of America. Göttingen: Vandenhoeck and Ruprecht.

Streib, H., \& Keller, B. (2004). The variety of deconversion experiences: Contours of a concept in respect to empirical research. Archive for the Psychology of Religion, 26(1), 181-200. 
Streib, H., \& Klein, C. (2013). Atheists, agnostics, and apostates. In K. Pargament (Ed.), APA handbook of psychology, religion and spirituality (pp. 713-728).

Washington, DC: American Psychological Association.

Taira, T. (2010). Religion as a discursive technique: The politics of classifying Wicca. Journal of Contemporary Religion, 25(3), 379-394.

Taira, T. (2012). Atheist spirituality: A follow on from New Atheism? Scripta Instituti Donneriani Aboensis, 24, 388-404.

Taira, T. (2013). The category of 'invented religion': A new opportunity for studying discourses on 'religion'. Culture and Religion, 14(4), 477-493.

Taira, T. (2014). Väärin uskottu? Ateismin uusi näkyvyys. Turku: Eetos.

Tajfel, H., \& Turner, J. C. (1979). An Integrative Theory of Intergroup Conflict. In W. G. Austin \& S. Worchel (Eds), The Social Psychology of Intergroup Relations (pp. 33-47). Monterey, CA: Brooks/Cole.

Travaglino, G. A., Abrams, D., de Moura, G. R., Marques, J. M., \& Pinto, I. R. (2014). How groups react to disloyalty in the context of intergroup competition: Evaluations of group deserters and defectors. Journal of Experimental Social Psychology, 54, 178-187.

Uzarevic, F., Saroglou, V., \& Muñoz-García, A. (2019). Are atheists unprejudiced? Forms of nonbelief and prejudice toward antiliberal and mainstream religious groups. Psychology of Religion and Spirituality. Advance online publication.

Van Camp, D., Barden, J., \& Sloan, L. (2016). Social and individual religious orientations exist within both extrinsic and extrinsic religiosity. Archiv für Religionspsychologie / Archive for the Psychology of Religion, 38(1), 22-46. 
Van Nieuwkerk, K . (ed.) (2018) Moving in and out of Islam. Austin: University of Texas Press.

Verkuyten, M. (2007). Religious group identification and inter-religious relations: A study among Turkish-Dutch Muslims. Group processes \& Intergroup relations, $10(3), 341-357$.

Verkuyten, M., \& Yildiz, A. A. (2007). National (dis)identification and ethnic and religious identity: A study among Turkish-Dutch Muslims. Personality and social psychology bulletin, 33(10), 1448-1462.

Vernon, G. M. (1968). The religious "nones": A neglected category. Journal for the Scientific Study of Religion, 7(2), 219-229.

Vignoles, V. L., \& Moncaster, N. J. (2007). Identity motives and in group favouritism: A new approach to individual differences in intergroup discrimination. British Journal of Social Psychology, 46(1), 91-113.

Von Hegner, I. (2016). Gods and Dictatorships: A Defence of Heroical Apatheism. Science, Religion and Culture, 3(1), 31-48.

Ysseldyk, R., Haslam, S. A., Matheson, K., \& Anisman, H. (2012). Love thine enemy? Evidence that (ir)religious identification can promote outgroup tolerance under threat. Group Processes \& Intergroup Relations, 15(1), 105-117.

Zuckerman, P. (2007). Atheism: contemporary numbers and patterns. In M. Martin (Ed.), The Cambridge Companion to Atheism (pp. 47-65). Cambridge: Cambridge University Press. 
This is an original manuscript / preprint of an article published by Taylor \& Francis in the International Journal for the Psychology of Religion on $30 \mathrm{Jul} 2020$, available at https://www.tandfonline.com/doi/full/10.1080/10508619.2020.1774206

Table 1: Descriptive statistics by country and deconversion status

\begin{tabular}{|c|c|c|c|c|c|c|c|c|c|c|c|}
\hline & & \multirow{2}{*}{$\mathrm{N}(\%)$} & \multirow{2}{*}{$\begin{array}{l}\text { Age } \\
M(S D)\end{array}$} & \multirow{2}{*}{$\begin{array}{l}\text { Gender } \\
\text { (\% } \\
\text { men) }\end{array}$} & \multirow{2}{*}{$\begin{array}{c}\text { Education } \\
\text { (\% } \\
\text { university } \\
\text { degree) }\end{array}$} & \multirow{2}{*}{$\begin{array}{l}\text { Political } \\
\text { orien- } \\
\text { tation } \\
M(S D)\end{array}$} & \multirow{2}{*}{$\begin{array}{l}\text { Religious } \\
\text { identity } \\
\text { M (SD) }\end{array}$} & \multirow{2}{*}{$\begin{array}{c}\text { Spiritual } \\
\text { identity } \\
\text { M (SD) }\end{array}$} & \multicolumn{3}{|c|}{ Feelings towards... } \\
\hline & & & & & & & & & $\begin{array}{l}\text { religious } \\
\text { majority } \\
M(S D)\end{array}$ & $\begin{array}{l}\text { religious } \\
\text { minorities } \\
\mathrm{M}(\mathrm{SD})\end{array}$ & $\begin{array}{c}\text { Muslims } \\
\text { M (SD) }\end{array}$ \\
\hline & & & & & & \multicolumn{3}{|c|}{ Scale 1 to 7} & \multicolumn{3}{|c|}{ Scale -50 to 50} \\
\hline \multirow{3}{*}{ Australia } & $\begin{array}{c}\text { De- } \\
\text { converts }\end{array}$ & $\begin{array}{c}85 \\
(52.5)\end{array}$ & $\begin{array}{c}44.51 \\
(18.12)\end{array}$ & 56.4 & 33.0 & $\begin{array}{c}3.81 \\
(1.26)\end{array}$ & $\begin{array}{c}1.85 \\
(1.16)\end{array}$ & $\begin{array}{c}2.48 \\
(1.52)\end{array}$ & $\begin{array}{l}10.00 \\
(20.67)\end{array}$ & $\begin{array}{c}7.72 \\
(22.73)\end{array}$ & $\begin{array}{c}4.00 \\
(28.60)\end{array}$ \\
\hline & $\begin{array}{l}\text { Lifelong } \\
\text { atheists }\end{array}$ & $\begin{array}{c}94 \\
(47.5)\end{array}$ & $\begin{array}{c}40.64 \\
(15.29)\end{array}$ & 45.9 & 35.3 & $\begin{array}{c}3.48 \\
(1.31)\end{array}$ & $\begin{array}{l}1.20 \\
(.63)\end{array}$ & $\begin{array}{c}1.69 \\
(1.03)\end{array}$ & $\begin{array}{c}-1.01 \\
(24.06)\end{array}$ & $\begin{array}{c}.33 \\
(24.32)\end{array}$ & $\begin{array}{c}1.06 \\
(31.05)\end{array}$ \\
\hline & Total & $\begin{array}{c}179 \\
(100.0)\end{array}$ & $\begin{array}{c}42.67 \\
(16.90)\end{array}$ & 51.4 & 34.1 & $\begin{array}{c}3.65 \\
(1.29)\end{array}$ & $\begin{array}{c}1.54 \\
(1.00)\end{array}$ & $\begin{array}{c}2.10 \\
(1.36)\end{array}$ & $\begin{array}{c}4.77 \\
(22.95)\end{array}$ & $\begin{array}{c}4.21 \\
(23.72)\end{array}$ & $\begin{array}{c}2.60 \\
(29.74)\end{array}$ \\
\hline \multirow{3}{*}{ Finland } & $\begin{array}{c}\text { De- } \\
\text { converts }\end{array}$ & $\begin{array}{c}75 \\
(40.5)\end{array}$ & $\begin{array}{c}48.41 \\
(18.30)\end{array}$ & 53.3 & 28.0 & $\begin{array}{c}3.32 \\
(1.64)\end{array}$ & $\begin{array}{l}2.19 \\
(.98)\end{array}$ & $\begin{array}{l}2.06 \\
(.99)\end{array}$ & $\begin{array}{c}8.16 \\
(21.34)\end{array}$ & $\begin{array}{c}3.72 \\
(20.03)\end{array}$ & $\begin{array}{c}.32 \\
(21.44)\end{array}$ \\
\hline & $\begin{array}{l}\text { Lifelong } \\
\text { atheists }\end{array}$ & $\begin{array}{c}110 \\
(59.5)\end{array}$ & $\begin{array}{c}48.62 \\
(15.75)\end{array}$ & 57.3 & 43.6 & $\begin{array}{c}3.43 \\
(1.72)\end{array}$ & $\begin{array}{l}1.76 \\
(.78)\end{array}$ & $\begin{array}{l}1.71 \\
(.72)\end{array}$ & $\begin{array}{c}6.43 \\
(20.37)\end{array}$ & $\begin{array}{c}1.45 \\
(19.68)\end{array}$ & $\begin{array}{c}-2.20 \\
(21.18)\end{array}$ \\
\hline & Total & $\begin{array}{c}185 \\
(100.0)\end{array}$ & $\begin{array}{c}48.54 \\
(16.78)\end{array}$ & 55.7 & 37.3 & $\begin{array}{c}3.39 \\
(1.68)\end{array}$ & $\begin{array}{l}1.94 \\
(.89)\end{array}$ & $\begin{array}{l}1.85 \\
(.85)\end{array}$ & $\begin{array}{c}7.15 \\
(20.74)\end{array}$ & $\begin{array}{c}2.39 \\
(19.80)\end{array}$ & $\begin{array}{c}-1.16 \\
(21.27)\end{array}$ \\
\hline \multirow{3}{*}{ Germany } & $\begin{array}{c}\text { De- } \\
\text { converts }\end{array}$ & $\begin{array}{c}55 \\
(25.9)\end{array}$ & $\begin{array}{c}47.18 \\
(17.71)\end{array}$ & 58.2 & 27.3 & $\begin{array}{c}3.58 \\
(1.27)\end{array}$ & $\begin{array}{l}1.41 \\
(.67)\end{array}$ & $\begin{array}{c}1.85 \\
(1.34)\end{array}$ & $\begin{array}{c}.00 \\
(26.72)\end{array}$ & $\begin{array}{c}-9.31 \\
(27.92)\end{array}$ & $\begin{array}{l}-13.24 \\
(27.57)\end{array}$ \\
\hline & $\begin{array}{l}\text { Lifelong } \\
\text { atheists }\end{array}$ & $\begin{array}{c}157 \\
(74.1)\end{array}$ & $\begin{array}{c}45.05 \\
(13.90)\end{array}$ & 50.3 & 27.4 & $\begin{array}{c}3.68 \\
(1.46)\end{array}$ & $\begin{array}{l}1.20 \\
(.69)\end{array}$ & $\begin{array}{l}1.46 \\
(.84)\end{array}$ & $\begin{array}{c}.20 \\
(26.98)\end{array}$ & $\begin{array}{l}-12.03 \\
(27.50)\end{array}$ & $\begin{array}{l}-16.75 \\
(29.33)\end{array}$ \\
\hline & Total & $\begin{array}{c}212 \\
(100.0)\end{array}$ & $\begin{array}{c}45.61 \\
(14.97)\end{array}$ & 52.4 & 27.4 & $\begin{array}{c}3.65 \\
(1.41)\end{array}$ & $\begin{array}{l}1.25 \\
(.69)\end{array}$ & $\begin{array}{c}1.56 \\
(1.01)\end{array}$ & $\begin{array}{c}.15 \\
(26.85)\end{array}$ & $\begin{array}{l}-11.33 \\
(27.57)\end{array}$ & $\begin{array}{l}-15.83 \\
(28.86)\end{array}$ \\
\hline \multirow{3}{*}{ Norway } & $\begin{array}{c}\text { De- } \\
\text { converts }\end{array}$ & $\begin{array}{c}68 \\
(37.4)\end{array}$ & $\begin{array}{c}42.35 \\
(12.39)\end{array}$ & 59.6 & 77.9 & $\begin{array}{c}3.24 \\
(1.58)\end{array}$ & $\begin{array}{l}1.21 \\
(.59)\end{array}$ & $\begin{array}{l}1.40 \\
(.69)\end{array}$ & $\begin{array}{l}-10.00 \\
(20.14)\end{array}$ & $\begin{array}{c}-9.51 \\
(18.18)\end{array}$ & $\begin{array}{c}-9.76 \\
(19.24)\end{array}$ \\
\hline & $\begin{array}{l}\text { Lifelong } \\
\text { atheists }\end{array}$ & $\begin{array}{c}114 \\
(62.6)\end{array}$ & $\begin{array}{c}44.44 \\
(12.78)\end{array}$ & 58.8 & 71.1 & $\begin{array}{c}3.16 \\
(1.57)\end{array}$ & $\begin{array}{l}1.10 \\
(.49)\end{array}$ & $\begin{array}{l}1.17 \\
(.63)\end{array}$ & $\begin{array}{l}-14.00 \\
(22.51)\end{array}$ & $\begin{array}{l}-11.76 \\
(24.02)\end{array}$ & $\begin{array}{l}-14.13 \\
(25.99)\end{array}$ \\
\hline & Total & $\begin{array}{c}182 \\
(100.0)\end{array}$ & $\begin{array}{c}43.66 \\
(12.64)\end{array}$ & 59.3 & 73.6 & $\begin{array}{c}3.19 \\
(1.57)\end{array}$ & $\begin{array}{l}1.14 \\
(.53)\end{array}$ & $\begin{array}{l}1.26 \\
(.66)\end{array}$ & $\begin{array}{l}-12.50 \\
(21.68)\end{array}$ & $\begin{array}{l}-10.92 \\
(22.01)\end{array}$ & $\begin{array}{l}-12.51 \\
(23.74)\end{array}$ \\
\hline \multirow{3}{*}{ Total } & $\begin{array}{c}\text { De- } \\
\text { converts }\end{array}$ & $\begin{array}{c}292 \\
(38.5)\end{array}$ & $\begin{array}{c}45.51 \\
(17.00)\end{array}$ & 56.5 & 41.1 & $\begin{array}{c}3.51 \\
(1.45)\end{array}$ & $\begin{array}{l}1.71 \\
(.99)\end{array}$ & $\begin{array}{c}1.99 \\
(1.26)\end{array}$ & $\begin{array}{c}2.99 \\
(23.28)\end{array}$ & $\begin{array}{c}-.49 \\
(23.42)\end{array}$ & $\begin{array}{c}-3.39 \\
(25.60)\end{array}$ \\
\hline & $\begin{array}{l}\text { Lifelong } \\
\text { atheists }\end{array}$ & $\begin{array}{c}466 \\
(61.5)\end{array}$ & $\begin{array}{c}44.98 \\
(14.54)\end{array}$ & 53.4 & 43.3 & $\begin{array}{c}3.46 \\
(1.53)\end{array}$ & $\begin{array}{l}1.31 \\
(.70)\end{array}$ & $\begin{array}{l}1.49 \\
(.83)\end{array}$ & $\begin{array}{c}-2.07 \\
(24.99)\end{array}$ & $\begin{array}{c}-6.59 \\
(25.18)\end{array}$ & $\begin{array}{c}-9.49 \\
(28.13)\end{array}$ \\
\hline & Total & $\begin{array}{c}758 \\
(100.0)\end{array}$ & $\begin{array}{c}45.16 \\
(15.53)\end{array}$ & 54.6 & 42.5 & $\begin{array}{c}3.48 \\
(1.50)\end{array}$ & $\begin{array}{l}1.46 \\
(.85)\end{array}$ & $\begin{array}{c}1.69 \\
(1.05)\end{array}$ & $\begin{array}{c}-.11 \\
(24.45)\end{array}$ & $\begin{array}{c}-4.23 \\
(24.67)\end{array}$ & $\begin{array}{c}-7.13 \\
(27.33)\end{array}$ \\
\hline
\end{tabular}


This is an original manuscript / preprint of an article published by Taylor \& Francis in the International Journal for the Psychology of Religion on $30 \mathrm{Jul} 2020$, available at https://www.tandfonline.com/doi/full/10.1080/10508619.2020.1774206

Table 2: Religious and spiritual identity among deconverted and lifelong atheists

\begin{tabular}{|c|c|c|c|c|c|c|c|c|c|c|}
\hline & & & \multirow[t]{2}{*}{$M$} & \multirow[t]{2}{*}{$S D$} & \multicolumn{2}{|c|}{$95 \% \mathrm{Cl}$} & \multirow[t]{2}{*}{$t$} & \multirow[t]{2}{*}{$d f$} & \multirow[t]{2}{*}{$p$} & \multirow[t]{2}{*}{$d$} \\
\hline & & & & & Lower & Upper & & & & \\
\hline \multirow{4}{*}{ 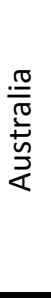 } & \multirow[t]{2}{*}{$\begin{array}{l}\text { Religious } \\
\text { identity }\end{array}$} & Deconverts & 1.85 & 1.16 & 1.61 & 2.09 & -4.73 & 146.11 & $<.001$ & .71 \\
\hline & & Lifelong atheists & 1.20 & .63 & 1.06 & 1.34 & & & & \\
\hline & \multirow[t]{2}{*}{$\begin{array}{l}\text { Spiritual } \\
\text { identity }\end{array}$} & Deconverts & 2.46 & 1.52 & 2.15 & 2.77 & -3.96 & 164.37 & $<.001$ & .59 \\
\hline & & Lifelong atheists & 1.69 & 1.03 & 1.47 & 1.92 & & & & \\
\hline \multirow{4}{*}{ 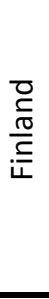 } & \multirow[t]{2}{*}{$\begin{array}{l}\text { Religious } \\
\text { identity }\end{array}$} & Deconverts & 2.19 & .98 & 1.96 & 2.41 & -3.12 & 134.86 & .002 & .47 \\
\hline & & Lifelong atheists & 1.76 & .78 & 1.62 & 1.91 & & & & \\
\hline & \multirow[t]{2}{*}{$\begin{array}{l}\text { Spiritual } \\
\text { identity }\end{array}$} & Deconverts & 2.06 & .99 & 1.83 & 2.29 & -2.61 & 126.01 & .010 & .39 \\
\hline & & Lifelong atheists & 1.71 & .72 & 1.58 & 1.85 & & & & \\
\hline \multirow{4}{*}{ 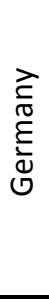 } & \multirow[t]{2}{*}{$\begin{array}{l}\text { Religious } \\
\text { identity }\end{array}$} & Deconverts & 1.41 & .67 & 1.23 & 1.59 & -2.01 & 96.78 & .047 & .31 \\
\hline & & Lifelong atheists & 1.20 & .69 & 1.09 & 1.31 & & & & \\
\hline & \multirow[t]{2}{*}{$\begin{array}{l}\text { Spiritual } \\
\text { identity }\end{array}$} & Deconverts & 1.85 & 1.34 & 1.48 & 2.21 & -1.99 & 69.61 & .051 & .31 \\
\hline & & Lifelong atheists & 1.46 & .84 & 1.33 & 1.59 & & & & \\
\hline \multirow{4}{*}{ 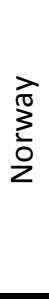 } & \multirow[t]{2}{*}{$\begin{array}{l}\text { Religious } \\
\text { identity }\end{array}$} & Deconverts & 1.21 & .59 & 1.07 & 1.36 & -1.32 & 120.53 & .191 & .20 \\
\hline & & Lifelong atheists & 1.10 & .49 & 1.01 & 1.19 & & & & \\
\hline & \multirow[t]{2}{*}{$\begin{array}{l}\text { Spiritual } \\
\text { identity }\end{array}$} & Deconverts & 1.40 & .69 & 1.24 & 1.57 & -2.27 & 130.69 & .025 & .35 \\
\hline & & Lifelong atheists & 1.17 & .63 & 1.05 & 1.29 & & & & \\
\hline \multirow{4}{*}{$\begin{array}{l}\bar{\pi} \\
\stackrel{0}{0} \\
\qquad\end{array}$} & \multirow[t]{2}{*}{$\begin{array}{l}\text { Religious } \\
\text { identity }\end{array}$} & Deconverts & 1.71 & .99 & 1.59 & 1.82 & -5.98 & 475.57 & $<.001$ & .45 \\
\hline & & Lifelong atheists & 1.31 & .70 & 1.24 & 1.37 & & & & \\
\hline & \multirow{2}{*}{$\begin{array}{l}\text { Spiritual } \\
\text { identity }\end{array}$} & Deconverts & 1.99 & 1.26 & 1.85 & 2.14 & -6.04 & 450.92 & $<.001$ & .45 \\
\hline & & Lifelong atheists & 1.49 & .83 & 1.42 & 1.57 & & & & \\
\hline
\end{tabular}


This is an original manuscript / preprint of an article published by Taylor \& Francis in the International Journal for the Psychology of Religion on $30 \mathrm{Jul} 2020$, available at https://www.tandfonline.com/doi/full/10.1080/10508619.2020.1774206

Table 3: Attitudes towards religious groups among deconverted and lifelong atheists

\begin{tabular}{|c|c|c|c|c|c|c|c|c|c|c|}
\hline & \multirow{2}{*}{$\begin{array}{l}\text { Feelings } \\
\text { towards... }\end{array}$} & & \multirow[t]{2}{*}{$M$} & \multirow[t]{2}{*}{$S D$} & \multicolumn{2}{|c|}{$95 \% \mathrm{Cl}$} & \multirow[t]{2}{*}{$t$} & \multirow[t]{2}{*}{$d f$} & \multirow[t]{2}{*}{$p$} & \multirow[t]{2}{*}{$d$} \\
\hline & & & & & Lower & Upper & & & & \\
\hline \multirow{6}{*}{ 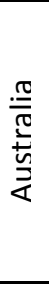 } & \multirow{2}{*}{$\begin{array}{l}\text { Religious } \\
\text { majority }\end{array}$} & Deconverts & 10.00 & 20.67 & 5.77 & 14.23 & \multirow{2}{*}{-3.27} & \multirow{2}{*}{166.54} & \multirow{2}{*}{.001} & \multirow{2}{*}{.49} \\
\hline & & Lifelong atheists & -1.01 & 24.06 & -6.20 & 4.18 & & & & \\
\hline & \multirow{2}{*}{$\begin{array}{l}\text { Religious } \\
\text { minorities }\end{array}$} & Deconverts & 7.72 & 22.72 & 3.07 & 12.38 & \multirow{2}{*}{-2.10} & \multirow{2}{*}{172.10} & \multirow{2}{*}{.038} & \multirow{2}{*}{.31} \\
\hline & & Lifelong atheists & .33 & 24.32 & -4.92 & 5.58 & & & & \\
\hline & \multirow{2}{*}{ Muslims } & Deconverts & 4.00 & 28.60 & -1.86 & 9.86 & \multirow{2}{*}{-.66} & \multirow{2}{*}{171.27} & \multirow{2}{*}{.512} & \multirow{2}{*}{.10} \\
\hline & & Lifelong atheists & 1.06 & 31.05 & -5.64 & 7.76 & & & & \\
\hline \multirow{6}{*}{ 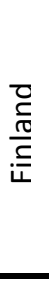 } & \multirow{2}{*}{$\begin{array}{l}\text { Religious } \\
\text { majority }\end{array}$} & Deconverts & 8.27 & 21.46 & 3.30 & 13.23 & \multirow{2}{*}{-.55} & \multirow{2}{*}{154.85} & 586 & Q \\
\hline & & Lifelong atheists & 6.02 & 20.02 & 2.15 & 9.89 & & & .500 & .00 \\
\hline & Religious & Deconverts & 3.77 & 20.17 & -.90 & 8.44 & -76 & 15771 & 451 & 11 \\
\hline & minorities & Lifelong atheists & .99 & 19.18 & -2.72 & 4.70 & -.10 & 101.11 & (4) & .11 \\
\hline & Muclims & Deconverts & .32 & 21.44 & -4.64 & 5.29 & 78 & 15621 & 127 & 12 \\
\hline & IVIustims & Lifelong atheists & -2.20 & 21.18 & -6.30 & 1.90 & -.18 & 130.31 & 15 & .12 \\
\hline & Religious & Deconverts & .00 & 26.72 & -7.22 & 7.22 & 05 & 9525 & 961 & 01 \\
\hline & majority & Lifelong atheists & .20 & 26.98 & -4.05 & 4.46 & (U) & 93.20 & .901 & .01 \\
\hline$\stackrel{\frac{1}{\pi}}{\varepsilon}$ & Religious & Deconverts & -9.31 & 27.92 & -16.86 & -1.76 & -63 & 9323 & 534 & 10 \\
\hline$\frac{\mathrm{c}}{\mathrm{c}}$ & minorities & Lifelong atheists & -12.03 & 27.50 & -16.37 & -7.70 & - & (50.25 & (534 & \\
\hline & Muslims & Deconverts & -13.24 & 27.57 & -20.69 & -5.78 & -80 & 9988 & 426 & 13 \\
\hline & IVIusitms & Lifelong atheists & -16.75 & 29.33 & -21.37 & -12.12 & -.80 & 99.88 & $.4 \angle 0$ & .13 \\
\hline & Religious & Deconverts & -10.15 & 20.26 & -15.09 & -5.21 & -124 & 15365 & 218 & 19 \\
\hline & majority & Lifelong atheists & -14.00 & 22.51 & -28.20 & -9.80 & -1.24 & 153.65 & .218 & .19 \\
\hline$\overbrace{}^{\pi}$ & Religious & Deconverts & -9.51 & 18.18 & -13.94 & -5.07 & 1 & 16755 & 178 & 11 \\
\hline 은 & minorities & Lifelong atheists & -11.76 & 24.02 & -16.24 & -7.28 & -.71 & $10 \%$ & $.4 / 0$ & .11 \\
\hline & Muslims & Deconverts & -9.76 & 19.24 & -14.45 & -5.07 & -129 & 16078 & 100 & 20 \\
\hline & IVIustims & Lifelong atheists & -14.13 & 25.99 & -18.98 & -9.29 & -1.29 & 109.28 & .199 &.$\angle 0$ \\
\hline & Religious & Deconverts & 2.99 & 23.28 & .31 & 5.71 & -282 & 65117 & - & 21 \\
\hline & majority & Lifelong atheists & -2.07 & 24.99 & -4.46 & .10 & -2.82 & 051.1/ & .005 & .21 \\
\hline $\bar{\pi}$ & Religious & Deconverts & -.49 & 23.42 & -3.21 & 2.21 & 237 & 61051 & (201 & 25 \\
\hline$\stackrel{0}{-}$ & minorities & Lifelong atheists & -6.59 & 25.18 & -9.01 & -4.41 & -3.31 & 049.54 & .001 & .25 \\
\hline & & Deconverts & -3.39 & 25.60 & -6.34 & -.43 & & 65694 & בחم0 & 23 \\
\hline & IVIusitms & Lifelong atheists & -9.49 & 28.13 & -12.07 & -6.92 & & 656.94 & .002 & .23 \\
\hline
\end{tabular}


Table 4: Correlations between variables

\begin{tabular}{|c|c|c|c|c|c|c|}
\hline & & Variables & 2 & 3 & 4 & 5 \\
\hline \multirow{5}{*}{ 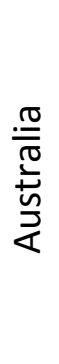 } & \multirow{5}{*}{ 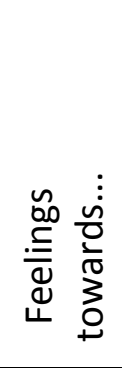 } & 1. Religious identity & $.624 * * *$ & $.225 * *$ & .137 & .141 \\
\hline & & 2. Spiritual identity & --- & $.151^{*}$ & .051 & .113 \\
\hline & & 3. Religious majority & & --- & $.639 * * *$ & $.435 * * *$ \\
\hline & & 4. Religious minorities & & & --- & $.756 * * *$ \\
\hline & & 5. Muslims & & & & --- \\
\hline \multirow{5}{*}{$\frac{\bar{D}}{\frac{C}{\sigma}}$} & \multirow{5}{*}{ 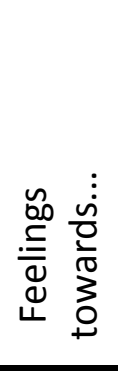 } & 1. Religious identity & $.657 * * *$ & $.173^{*}$ & .124 & .143 \\
\hline & & 2. Spiritual identity & --- & .129 & .122 & .057 \\
\hline & & 3. Religious majority & & --- & $.618^{* * *}$ & $.408^{* * *}$ \\
\hline & & 4. Religious minorities & & & --- & $.788 * * *$ \\
\hline & & 5. Muslims & & & & --- \\
\hline \multirow{5}{*}{$\begin{array}{l}\underset{c}{\frac{1}{\sigma}} \\
\frac{c}{d} \\
\stackrel{0}{0}\end{array}$} & \multirow{5}{*}{ 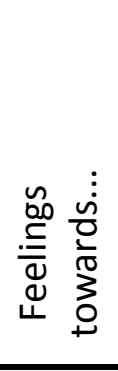 } & 1. Religious identity & $.410^{* * *}$ & .111 & .119 & .134 \\
\hline & & 2. Spiritual identity & --- & .052 & .029 & .008 \\
\hline & & 3. Religious majority & & --- & $.569 * * *$ & $.510 * * *$ \\
\hline & & 4. Religious minorities & & & --- & $.831^{* * *}$ \\
\hline & & 5. Muslims & & & & --- \\
\hline \multirow{5}{*}{$\begin{array}{l}\text { ते } \\
\sum_{0}^{2} \\
2\end{array}$} & \multirow{5}{*}{ 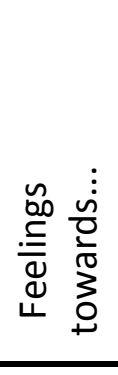 } & 1. Religious identity & $.635^{* * *}$ & $.308^{* * *}$ & $.284^{* * *}$ & $.241^{* *}$ \\
\hline & & 2. Spiritual identity & --- & $.303^{* * *}$ & $.246^{* *}$ & $.177^{*}$ \\
\hline & & 3. Religious majority & & --- & $.861^{* * *}$ & $.740 * * *$ \\
\hline & & 4. Religious minorities & & & --- & $.877^{* * *}$ \\
\hline & & 5. Muslims & & & & --- \\
\hline \multirow{5}{*}{$\begin{array}{l}\bar{\pi} \\
\stackrel{0}{0} \\
\qquad\end{array}$} & \multirow{5}{*}{ 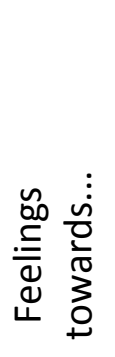 } & 1. Religious identity & $.586 * * *$ & $.254^{* * *}$ & $.218^{* * *}$ & $.212 * * *$ \\
\hline & & 2. Spiritual identity & --- & $.201 * * *$ & $.155^{* * *}$ & $.144 * * *$ \\
\hline & & 3. Religious majority & & --- & $.664 * * *$ & $.528 * * *$ \\
\hline & & 4. Religious minorities & & & --- & $.825 * * *$ \\
\hline & & 5. Muslims & & & & --- \\
\hline
\end{tabular}

${ }^{*} p<.05,{ }^{* *} p<.01,{ }^{* * *} p<.001$ 
Table 5: Regression models of attitudes towards religious groups (Model 1 without and Model 2 with religious and spiritual identity)

\begin{tabular}{|c|c|c|c|c|c|c|}
\hline & \multicolumn{2}{|c|}{$\begin{array}{l}\text { Feelings towards } \\
\text { religious majority }\end{array}$} & \multicolumn{2}{|c|}{$\begin{array}{l}\text { Feelings towards } \\
\text { religious minorities }\end{array}$} & \multicolumn{2}{|c|}{$\begin{array}{l}\text { Feelings towards } \\
\text { Muslims }\end{array}$} \\
\hline & $\begin{array}{l}\text { Model } 1 \\
\text { beta }\end{array}$ & $\begin{array}{l}\text { Model } 2 \\
\text { beta }\end{array}$ & $\begin{array}{l}\text { Model } 1 \\
\text { beta }\end{array}$ & $\begin{array}{l}\text { Model } 2 \\
\text { beta }\end{array}$ & $\begin{array}{l}\text { Model } 1 \\
\text { beta }\end{array}$ & $\begin{array}{l}\text { Model } 2 \\
\text { beta }\end{array}$ \\
\hline Gender & .05 & .05 & .04 & .04 & .07 & .06 \\
\hline Age & -.04 & -.03 & -.06 & -.05 & $-.11^{* *}$ & $-.10^{* *}$ \\
\hline Country (AUS) & -.05 & -.02 & .04 & .07 & .05 & $.10^{*}$ \\
\hline Country (DEU) & $-.12 *$ & -.06 & $-.22 * * *$ & $-.17 * * *$ & $-.22 * * *$ & $-.16 * * *$ \\
\hline Country (NOR) & $-.35 * * *$ & $-.28 * * *$ & $-.26 * * *$ & $-.20 * * *$ & $-.21 * * *$ & $-.14 * *$ \\
\hline University degree & .04 & .04 & $.08^{*}$ & $.08^{*}$ & .05 & .05 \\
\hline Political orientation & .05 & .03 & $-.15 * * *$ & $-.16 * * *$ & $-.19 * * *$ & $-.21 * * *$ \\
\hline Deconversion status & $.10 * *$ & .06 & $.08^{*}$ & .05 & $.07^{*}$ & .04 \\
\hline Religious identity & & $.16^{* *}$ & & $.16^{* *}$ & & $.17^{* * *}$ \\
\hline Spiritual identity & & .04 & & .00 & & -.01 \\
\hline $\mathrm{R}^{2}$ & .11 & .13 & .13 & .15 & .14 & .16 \\
\hline $\mathrm{F}$ & $10.99 * * *$ & $11.27 * * *$ & $13.22 * * *$ & $12.50 * * *$ & $14.89 * * *$ & $14.20 * * *$ \\
\hline$\Delta R^{2}$ & .11 & .03 & .13 & .02 & .14 & .02 \\
\hline$\Delta \mathrm{F}$ & $10.99 * * *$ & $11.15^{* * *}$ & $13.22 * * *$ & $8.53^{* * *}$ & $14.89 * * *$ & $9.98 * * *$ \\
\hline
\end{tabular}

${ }^{*} p<.05,{ }^{* *} p<.01, * * * p<.001$ 
Table 6: Direct and indirect effects of deconversion status on attitudes towards the religious majority (Model 1), minorities (Model 2), and Muslims (Model 3)

$\begin{array}{ccc}\text { Model } 1 & \text { Model 2 } & \text { Model 3 } \\ (N=741) & (N=740) & (N=739)\end{array}$

\begin{tabular}{|c|c|c|c|c|c|c|}
\hline \multirow{2}{*}{$\begin{array}{l}\text { Dependent } \\
\text { variable (DV) } \\
\text { Mediator } \\
\text { variable (MV) }\end{array}$} & \multicolumn{2}{|c|}{$\begin{array}{l}\text { Feelings towards } \\
\text { religious majority }\end{array}$} & \multicolumn{2}{|c|}{$\begin{array}{l}\text { Feelings towards } \\
\text { religious minorities }\end{array}$} & \multicolumn{2}{|c|}{$\begin{array}{l}\text { Feelings towards } \\
\text { Muslims }\end{array}$} \\
\hline & $\begin{array}{l}\text { Religious } \\
\text { identity }\end{array}$ & $\begin{array}{l}\text { Spiritual } \\
\text { identity }\end{array}$ & $\begin{array}{l}\text { Religious } \\
\text { identity }\end{array}$ & $\begin{array}{l}\text { Spiritual } \\
\text { identity }\end{array}$ & $\begin{array}{l}\text { Religious } \\
\text { identity }\end{array}$ & $\begin{array}{l}\text { Spiritual } \\
\text { identity }\end{array}$ \\
\hline $\begin{array}{l}\text { Total effect: } \\
\text { IV } \rightarrow \text { DV } \\
b(S E)\end{array}$ & \multicolumn{2}{|c|}{$2.43 * *(.89)$} & \multicolumn{2}{|c|}{$2.12 *(.89)$} & \multicolumn{2}{|c|}{$2.00 *(.98)$} \\
\hline $\begin{array}{l}\text { Direct effect: } \\
\text { IV } \rightarrow \text { DV } \\
b(S E)\end{array}$ & \multicolumn{2}{|c|}{$1.43(.90)$} & \multicolumn{2}{|c|}{$1.28(.91)$} & \multicolumn{2}{|c|}{$1.04(1.00)$} \\
\hline $\begin{array}{l}\text { Effect: } \\
\text { IV } \rightarrow \mathrm{MV} \\
b(S E)\end{array}$ & $\begin{array}{l}.18 * * * \\
(.03)\end{array}$ & $\begin{array}{c}.22 * * * \\
(.04)\end{array}$ & $\begin{array}{l}.18^{* * *} \\
(.03)\end{array}$ & $\begin{array}{c}.22 * * * \\
(.04)\end{array}$ & $\begin{array}{c}.18^{* * *} \\
(.03)\end{array}$ & $\begin{array}{c}.22 * * * \\
(.04)\end{array}$ \\
\hline $\begin{array}{l}\text { Effect: } \\
\mathrm{MV} \rightarrow \mathrm{DV} \\
b(S E)\end{array}$ & $\begin{array}{c}4.52 * * * \\
(1.31)\end{array}$ & $\begin{array}{c}.82 \\
(1.03)\end{array}$ & $\begin{array}{c}4.50 * * * \\
(1.31)\end{array}$ & $\begin{array}{c}.04 \\
(1.04)\end{array}$ & $\begin{array}{c}5.60 * * * \\
(1.45)\end{array}$ & $\begin{array}{l}-.31^{*} \\
(1.14)\end{array}$ \\
\hline $\begin{array}{l}\text { Indirect effect: } \\
\text { IV } \rightarrow \mathrm{MV} \rightarrow \mathrm{DV} \\
{[95 \% \mathrm{Cl}]}\end{array}$ & $\begin{array}{c}.82 \\
{[.22,1.55]}\end{array}$ & $\begin{array}{c}.18 \\
{[-.43, .73]}\end{array}$ & $\begin{array}{c}.82 \\
{[.26,1.45]}\end{array}$ & $\begin{array}{c}.01 \\
{[-.51, .56]}\end{array}$ & $\begin{array}{c}1.03 \\
{[.40,1.69]}\end{array}$ & $\begin{array}{c}-.07 \\
{[-.65, .52]}\end{array}$ \\
\hline $\begin{array}{l}\text { Standardised } \\
\text { indirect effect } \\
{[95 \% \mathrm{Cl}]}\end{array}$ & $\begin{array}{c}.03 \\
{[.01, .06]}\end{array}$ & $\begin{array}{c}.01 \\
{[-.02, .03]}\end{array}$ & $\begin{array}{c}.03 \\
{[.01, .06]}\end{array}$ & $\begin{array}{c}.00 \\
{[-.02, .02]}\end{array}$ & $\begin{array}{c}.04 \\
{[.01, .06]}\end{array}$ & $\begin{array}{c}-.00 \\
{[-.02, .02]}\end{array}$ \\
\hline
\end{tabular}

